\title{
中性子散乱による高分子系の高次構造形成過程とダイナミクスの解明
}

\section{Formation Process of Higher Order Structure and Dynamics of Polymers by Neutron Scattering}

\section{0

\begin{abstract}
In this article we review our recent studies on polymer structure and dynamics using neutron scattering techniques, including three topics, (i) glassy dynamics of polymer thin films, (ii) polymer crystallization under flow and (iii) nanometer scale dynamics of poly (vinyl alcohol) gels by neutron spin-echo measurements.
\end{abstract}

金谷 利治

（京都大学 化学研究所）

Toshiji Kanaya

Institute for Chemical Research, Kyoto University

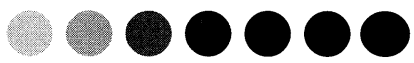

1.はじめに

平成 19 年度の日本中性子科学会学会賞を表題 の研究テーマで受賞させていただいた.さらには, 学会誌「波紋」に受賞記事まで書かせていただく ことになり，身に余る光栄である。これまで，中 性子散乱を用いて多くの高分子研究をさせていた だいてきたが，受賞の対象になったテーマには結 構長く行ってきたものもある.すべてをアブスト ラクト的に書くのはあまり面白くないので，いく つかのテーマに絞ろうと考えた。 しかし，どのテ 一マについて書こうかと考えると難しい，という のは，私自身，結構浮気性で高分子系については いろいろなテーマについて研究してきたし，また 中性子散乱という手法から見ても，粉末回折，小 角散乱, 超小角散乱, 反射率, 非弾性散乱, スピ ンエコー測定など多くの分光器を使い実験をさせ ていただいた（これは，分光器を持たない私にと っては,多くの人に世話になったことを意味する) あまり古い話を書くのも気が引けるので，本稿で は比較的新たな以下の 3 つのテーマに絞って書く ことにした。一つは, 非弾性散乱による高分子薄 膜のガラスダイナミクスであり, 二つ目は流動場 における高分子結晶化，そして三つ目は高分子ゲ ルのスローダイナミクスである.それぞれのテー マに思い出もあるので, それらも交えて書いてみ ることにした.

2. 高分子薄膜のガラスダイナミクス

高分子薄膜の研究は 90 年代初頭より, エリプソ メトリ一[1], ブリリュアン散乱[2]や表面弾性率測 定[3]により非常に活発に行われるようになって いた. 我々も中性子およびX線反射率測定により, 高分子薄膜の異常現象を調べていた[4]. それらの 研究の興味深い結果の一つは, 高分子薄膜のガラ ス転移温度の膜厚の低下による減少であった。さ
らに, 薄膜になるとガラス状態の熱膨張係数も減 少することが示されていた. 前者の原因の最も確 からしい解釈は, 高分子薄膜の表面に分子運動性 の高い層が存在し, 膜厚の減少に伴いその高運動 性の層の分率が高くなるため, ガラス転移温度が 下がるというものであった。 もっともらしい説明 である.しかし，熱膨張係数の減少については， 何ら説明がなかった。これらの問題を明らかにす るため, 高分子薄膜の非弾性中性子散乱を始めた のである.ちょうど，そのころ研究室に配属され た井上倫太郎君が非弾性散乱に興味を持ってくれ たこともこのテーマを進める大きな切掛けとなり， 実際彼がほとんどの実験を行った.

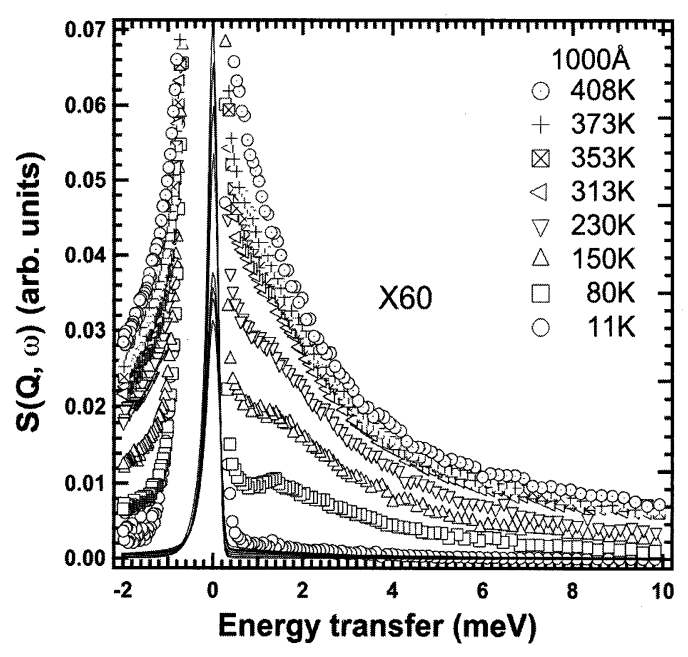

Fig. 1. Dynamic scattering law $S(Q, \omega)$ of the polystyrene thin film $(100 \mathrm{~nm})$ measured by LAM-40.

最初にぶつかった問題は，非常に少量の高分子 薄膜（例えば， $100 \mathrm{~nm}$ のポリスチレン薄膜 1 枚 で, 約 $0.1 \mathrm{mg}$ ）からの弱い散乱強度である. 水素 
の非干渉性散乱がいかに強いとはいえ，現時点で の中性子強度では測定不可能である。少々恥ずか しいが，強引に力ずくで測定を行うことにした. すなわち，バックグランドを減らすためにアルミ 䇴上に薄膜を準備し，それを 300 枚作成した。こ れは，井上君の努力の成果である。それでも散乱 強度は弱い. S/N の悪い分光器では, いくら長時 間測定しても S/N 限界のためシグナルを取り出せ ない.このときほど，KENSの LAM-40 の低バッ クグラウンドをありがたく感じたことはなかった。 中性子強度は弱くても， $\mathrm{S} / \mathrm{N}$ がよいため測定時間 をかければ，確実にシグナルが取り出せた。

LAM-40（エネルギー分解能 $0.2 \mathrm{meV}$ ）により世界 で始めて測定された厚さ $100 \mathrm{~nm}$ のポリスチレン 薄膜のガラス転移温度 $(=373 \mathrm{~K})$ 以下における動 的散乱則 $S(Q, \omega)$ を図 1 に示す [5,6]. ISIS の MARI (エネルギー分解能 $0.35 \mathrm{meV}$ ) でも同様の測定を 行い,ほぼ同じ結果を得た。

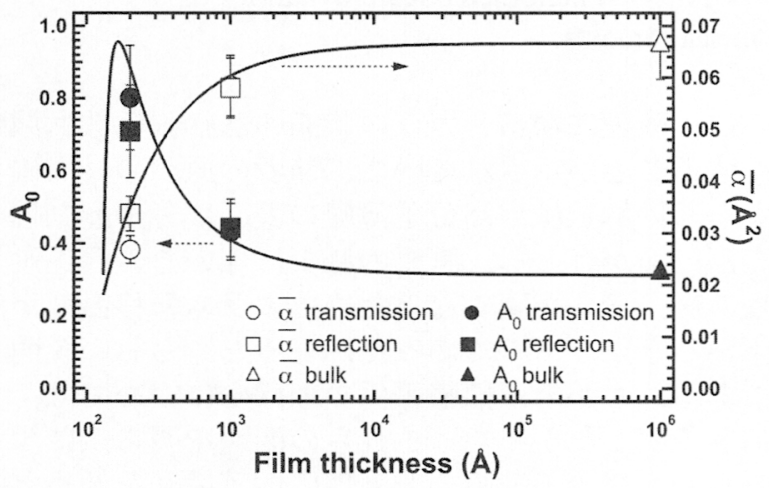

Fig. 2. Mean square displacement $\left\langle u^{2}\right\rangle$ and non-Gaussian parameter $A_{0}$ as a function of film thickness at $230 \mathrm{~K}$. Solid lines are the results of fits with bi-layer model.

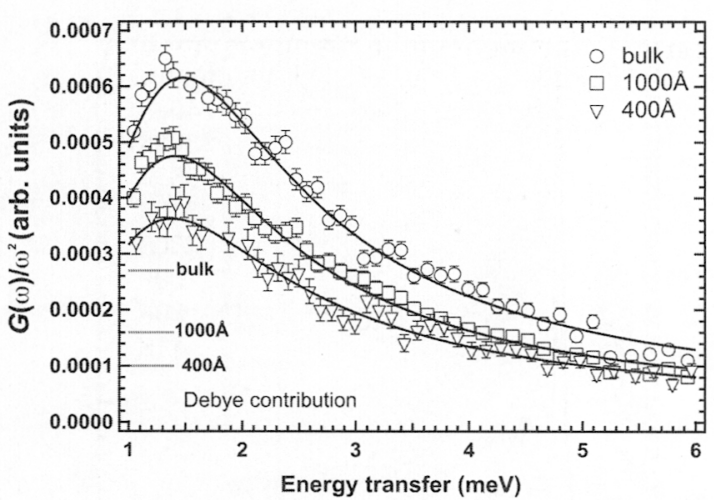

Fig. 3. Density of phonon states of polystyrene thin films for 100 and $40 \mathrm{~nm}$ films.

平均自乗変位 $\left\langle u^{2}\right\rangle(=\bar{\alpha})$ を評価し，その膜厚 依存性を調べた（図 2)。膜厚の減少に従い，ガラ ス状態では $<u^{2}>$ が減少した。すなわち，ガラス 状態では，膜厚が減少すると高分子は固くなると 結論された。実際, 非弾性散乱より評価したフォ ノンの状態密度（図 3）においても，膜厚低下に
従い，その減少が観測された。この原因として， （1）薄膜中の高分子鎖の拘束効果と，(2)基板界面 に高分子の配向による固い層の生成が予想された。 この問題については，異なる分子量の試料を用い た同一膜厚の試料について測定を行い, $<u^{2}>の$ 分子量依存性がないことを確認し, $<u^{2}>$ 減少の 原因が基板界面に存在する固い層であることを明 らかにした[7].ここでの結果は, 膜厚が薄くなる ほど基板界面の固い層のために薄膜は固くなると 主張する。一方, 本結果は膜厚が薄くなると表面 の高運動性の層のためにガラス転移温度が低くな るという解釈と矛盾するように思える。この矛盾 は，高分子薄膜が非常に動的に不均一であること を示唆する。すなわち, ガラス転移温度を見ると きには，表面の高運動性の層が主原因となるが， ガラス状態の運動性は基板界面の固い層が主原因 であると考えられる。この動的不均一性の評価を, 非ガウスパラメーター $A_{0}$ より行った[8].この評 価には，高エネルギー分解で高い $Q$ までの測定が 要求されるため, ISIS の MARI 分光器 (入射工 ネルギー $E i=15 \mathrm{meV})$ 老用いて行った. 図 2 にMARI で測定した非ガウスパラメーター $A_{0}$ を膜厚の関 数として示した。バルクのガラスポリスチレンに 固有の動的不均一性に由来する $A_{0}$ に加え, 基板界 面の固い層の存在に由来する動的不均一性のため $A_{0}$ は膜厚の減少に従い, 増大寸ることが本研究で 始めて示された。界面の固い層とバルク的な層の 2 層モデルで解析することにより, 固い界面層の 厚さが $13 \mathrm{~nm}$ と求まった。今後, 薄膜研究の最大 の課題の一つは, 動的不均一性よりもたらされる ガラス転移温度の分布をあらわに示すことであろ う。

\section{3. 流動場における高分子結晶化}

高分子を伸長流動やせん断流動の場で結晶化さ せるといわゆるシシケバブと呼ばれる特異な高次 構造が形成される。この名前はトルコ料理の焼さ 肉「シシケバブ」に由来する。シシと呼ばれる伸 長鎖結晶の回りに，尔バブと呼ばれる折り畳み鎖 結晶がオーバーグロースしたと考えられている。 この構造が高弾性率・高強度繊維の構造的起源で あると考えられているため多くの研究が行われて きているが，その生成機構が明らかにされておら ず，高弾性率緎維開発のためにもその機構解明が 待ち望まれている。
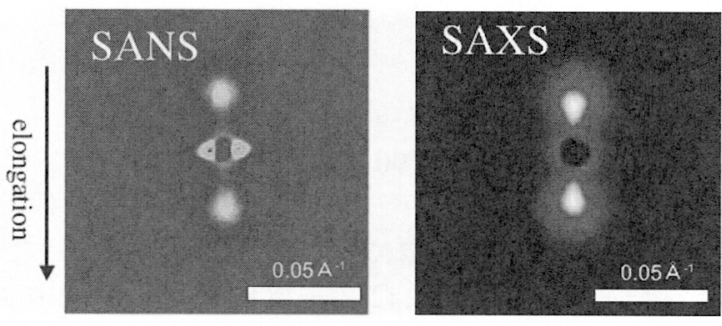

Fig. 4. 2D SANS and SAXS patterns of elongated blends of deuterated polyethyelene (PE) and ultra-high molecular weight protonate PE. 
時代の要請もあり, 産業応用にも比較的近いこ のテーマに我々もここ数年，レーザー光散乱，放 射光 X線散乱および中性子散乱などを用いて取り 組んできた[9-11]. 光散乱より, シシケバブ生成に はマイクロメートルスケールの配向構造物（シシ 前駆体と呼ぶ）がシシ以前に生成していることが 示され，シシケバブ形成にはこの前駆体生成が大 きな役割をしていることが示唆された。しかし， その定量的なサイズやまた高弾性率を支えている と考えられている伸長鎖結晶（シシ）とこの前駆 体の関係は不明のままであった。この問題に中性 子散乱が決着を付けた。シシは以前より試料中の 高分子量成分から形成されると考えられていたし， また前駆体も高分子量成分によりその生成が促進 される[12]. これらのことを参考にし，重水素化 ポリエチレン（d-PE）に超高分子量水素化ポリエ チレン（h-PE）を $2.8 \mathrm{wt} \%$ 混ぜたものを融点直下で 6 倍延伸したものを試料として作成し，小角中性 子散乱（SANS）と小角放射光 X 線散乱（SAXS） を行った[11]. この実験のアイデアは簡単で, も しシシもしくはシシ前駆体が超高分子量成分から できていれば，軽水素と重水素の大きな散乱長の 差により強い散乱コントラストが中性子散乱には つくが，X線散乱には付かないことが予想される. その場合には, 中性子データの解析よりシシもし くはシシ前駆体の形状因子が定量的に評価できる. 逆に超高分子量成分が系に均一に分散していれば, 中性子とX線のデータはよく似たものになると予 想される.

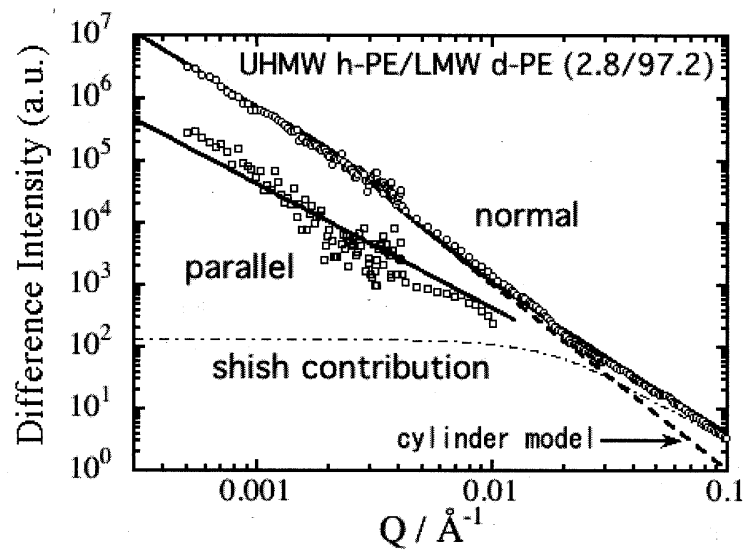

Fig. 5. 1D SANS difference intensities in directions normal and parallel to the elongation direction after subtraction of contributions of density fluctuations which were evaluated from SAXS data. Thick solid lines are the results of fit to multicore-shell cylinder model and thin chain line is a contribution of the core [or the shish (extended chain crystal)]. Thick dashed line is the result of fit to the cylinder model.

図 4 に SANS およびSAXS の 2 次元データを示す. SANS データにはケバブ由来の延伸方向に平行方 向の 2 スポットパターンに加え, シシもしくはシ シ前駆体由来の延伸方向に垂直な方向のストリー
ク状の散乱が強く観察された。一方， SAXS デー タにはケバブ由来の 2 スポットパターンは観測さ れるが，シシもしくはシシ前駆体由来の散乱は観 測されなかった。この結果より，シシもしくはシ シ前駆体は超高分子量成分から形成されているこ とが直接結論できる。さらに，シシケバブ構造の 定量評価のため，KENS の飛行時間小角散乱装置

（SWAN）および中性子レンズを装着した SANS-J を用い測定 $Q$ 範囲を $2 \times 10^{-4} \sim 3 \AA^{-1}$ まで大きく広 げた。角中性子散乱コントラストは軽水素と重 水素の散乱長密度の相違から来るものと密度摇ら ぎに起因するものがあるが，シシもしくはシシ前 駆体の形状因子を見積もるために，X 線データを 用い，軽水素と重水素の散乱長の相違による摇ら ぎのみを評価した（図 5)。このデータを多重コア ーシェルモデルを用いて解析した結果が図中の太 い実線で示されている。これより, 直径 $2 \mu \mathrm{m}$ で 長さが約 $12 \mu \mathrm{m}$ のシシ前駆体が超高分子量成分か ら形成され，その中に直径 $9 \mathrm{~nm}$ のシシ（すなわ ち，伸長鎖結晶）が 3 本存在することが明らかと なった. 2 種類の模式図を図 6 に示す。これによ り, 光散乱から予想されたシシ前駆体の存在が延 伸試料においても観測され，その存在がかなり普 遍的であることが示された．現在，このシシ前駆 体の生成機構の解明が急ピッチで進められている.
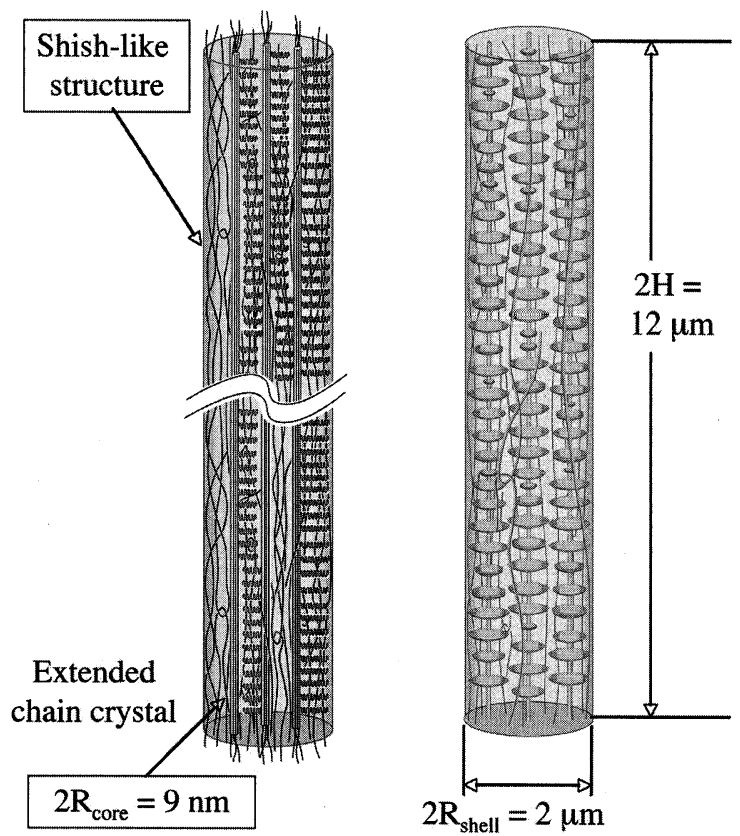

Fig. 6. Two schematic sketches of shish-kebab, including a precursor of shish-kebab.

4. 高分子ゲルのスローダイナミクス

高分子系のダイナミクスの研究には粘弾性測定 が大きな役割を担っている。また，レーザーの出 現により干渉性の高いビームが容易に手に入るよ うになり，光子相関法による高分子ダイナミクス の研究も盛んである。しかし，ナノメートルスケ 一ルの構造とダイナミクスを同時に測定できると なるとその手段は限られており，その意味で中性 
子スピンエコー（NSE）法はユニークな測定法で ある。

私が中性子スピンエコーの測定を始めて行った のは 1985 年のグルノーブル ILL の IN11 であった。 当時, 日本にはまだスピンエコー装置がなく, 後 に東海村JRR-3にNSE を作成されることになる広 島大学の好村先生, 武田先生が KUR に試作機を 作万うとされておられた。今回, 武田先生がその 業績で日本中性子科学会技術賞を受賞されたが, その装置を使わせていただいた者として，同時に 受賞させていただくことは非常に栄誉に感じる. 武田先生の装置なくしては, 私の研究は成り立っ ていなかったと思う。心より感謝したい. 日本人 だけの著者名で NSE の論文が書けるようになっ たのは感慨深い.
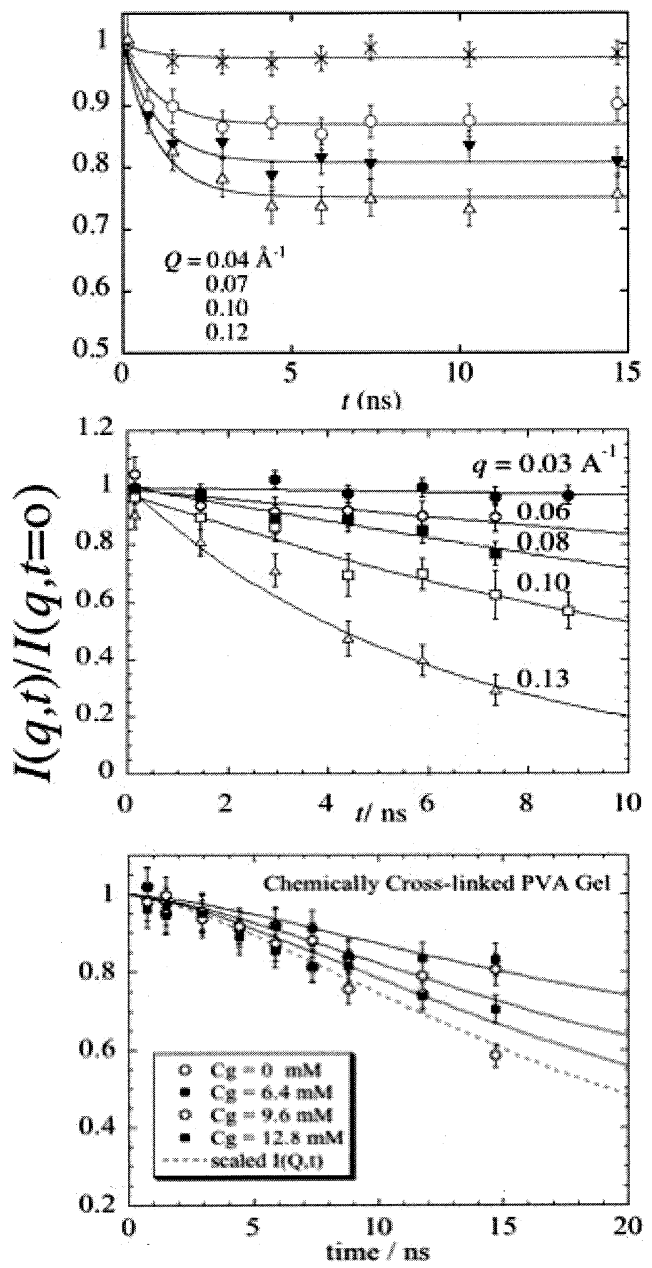

Fig. 7. Normalized intermediate scattering function $I(q, t) / I(q, t=0)$ of three sorts of PVA gels. Physical gel, hydrogen bonding gel and chemical gel (from top to bottom).

ここでは NSE を用いた高分子スローダイナミ クスの研究の一例として，ポリビニルアルコール (PVA) ゲルのナノメートルスケールのダイナミ クス研究を取り上げる[13,14]. PVA ゲルは水溶性 であり，生体親和性も高く医療材料などとして古
くから調べられており，その架橋方法の相違によ り物性の大きく異なるゲルが生成することが知ら れている，我々は，小角中性子散乱を用いて古く からその構造研究を行い，生成機構を明らかにし てきた $[15,16]$. しかし，ダイナミクスの研究がな く, ゲルの温度変化等の外場への応答の理解が進 まなかった. 本研究では, ジメチルスルホキシド

（DMSO）と水の混合溶媒中で生成する微結晶を 架橋点とする物理ゲル（微結晶ゲルと呼ぶ）[13] とホウ砂を添加して形成される水素結合を架橋点 とする架橋点交換可能なゲル（水素結合ゲルと呼 ぶ）[13] およびグルタールアルデヒドによる化学 架橋ゲル（化学架橋ゲルと呼ぶ）[14]を取り上げ た。
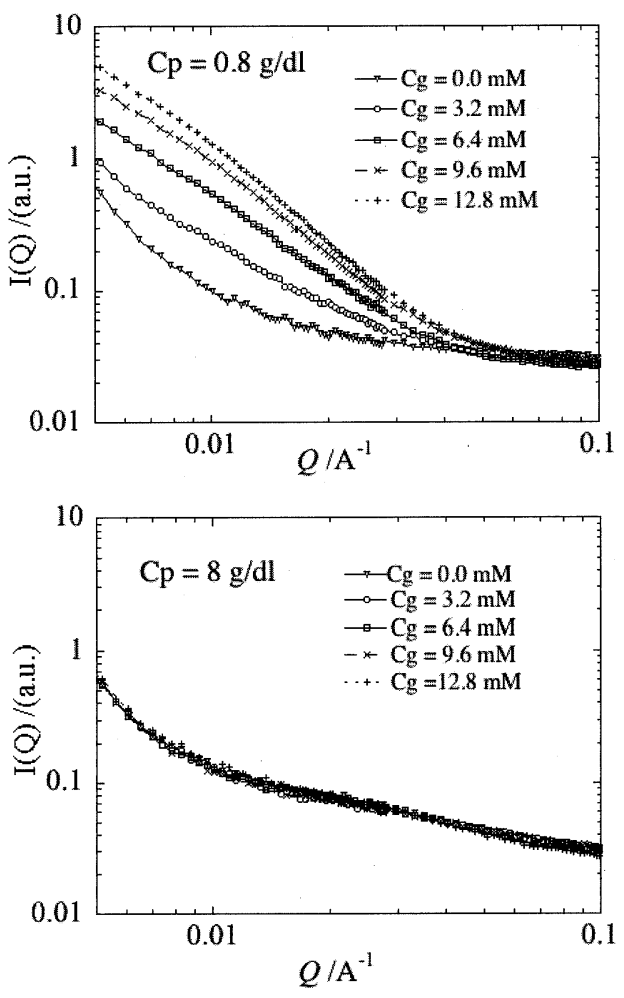

Fig. 8. SANS profiles of chemical cross-linking PVA gels with PVA concentration of 0.8 and $8 \mathrm{~g} / \mathrm{dl}$ for various degrees of cross-linking.

東海村原子力研究所 (現: JAEA) の JRR-3 の iNSE 装置を用いて規格化中間散乱関数 $I(q, t) / I(q, t=0)$ を 測定した結果を図 7 に示す。微結晶ゲルでは中間 散乱関数は 3 ナノ秒で少し減衰するが，その後は 全く緩和しない，すなわち，非常に速い運動をす る部分とほとんど動かない部分からできている不 均一なゲルであることが分かる．それに対して， 水素結合ゲルの中間散乱関数は同濃度の PVA 溶 液と同じとなり，マクロな粘度が 5 桁以上異なる にもかかわらずナノメートルスケールで見ると溶 液と全く同じ運動をしていることが明らかになっ た。一方, 化学架橋ゲルでは PVA 濃度が $8 \mathrm{~g} / \mathrm{dl}$ と 高いときには，中性子小角散乱で測定した静的な 構造は架橋点濃度に全く依存せず，同じゲルに見 える（図 8）[17]. しかし，中性子スピンエコー法 
で測定すると架橋点濃度の増加に従い, ナノメー トルスケールでは動いていない成分が増大してい くのが観察された，すなわち，静的な摇らぎは同 じでも動的には区別できるゲルであることが分か り,ゲルの外場応答に対する理解が非常に進んだ.

\section{5.おおりに}

高分子に代表されるソフトマターの研究が中性 子散乱のみにより進むことはない。しかし, 中性 子がいくつかの未解決問題に最終結論を与えてき たことも確かである。それに魅せられてここまで 高分子の中性子散乱研究を続けてきた.ここでは, その幾つかを紹介させていただいた。これまでの 中性子は強度が弱く, 研究できる系の制約が大き かったことは否定できない.ここで述べた高分子 薄膜の研究も, ある意味無理をした研究であった. 現在建設中の大型陽子加速器施設 (J-PARC) の物 質・生命科学研究施設 (MLF) が稼働を開始すれ ば，今までとは質の違う新たな測定が始まり，新 たな基礎研究や応用研究が開始され，そこから生 まれる成果は計り知れない。期待が高まる。しか し，大切なことは，研究者が新たな装置をどれだ けうまく使いこなし，よいテーマを見つけられる かである．装置に振り回される研究であってはな らない。

中性子のように大型施設を利用する研究は一人 ではできず，研究を進めるにあたり非常に多くの 方々のお世話になった。最後になったが，心より お礼を申し上げたい。特に, 北丸竜三京大名誉教 授，梶慶輔京大名誉教授，西田幸次准教授，大倉 正寿博士，松葉豪助教，高橋伸明博士，井上倫太 郎博士をはじめ研究室に在籍するもしくは在籍さ れた方々，非弾性散乱においては，故井上和彦北 大教授，鬼柳善明教授，柴田董博士，川口辰也博 士，筑紫格博士，スピンエコー測定においては， 武田隆義教授，瀬戸秀紀教授，長尾道弘博士，加 倉井和久博士，小角散乱においては，古坂道弘教 授, 今井正幸教授, 松下裕秀教授, 柴山充弘教授, 清水裕彦教授，大友季哉准教授，全散乱では，三 沢正勝教授，反射率測定においては，海老沢徹博 士, 田崎誠司准教授, 日野正裕准教授，鳥飼直也 准教授, 施設関係では, 遠藤康夫東北大名誉教授, 藤井保彦量子ビーム応用研究部門長, 池田進教授, 新井正敏博士，福永俊晴教授，吉沢英樹教授，山 田和芳教授に感謝する．そして，きっとここで私 が名前を挙げるのを忘れている非常にお世話にな った方々に感謝する。
参考文献

[1] J. L. Keddie, R. A. L. Jones and R. A. Cory, Faraday Discusssion 98, 219 (1994).

[2] J. A. Forrest, K. Dalnoki-Veress, J. R. Stevens and J. R. Dutcher, Phys. Rev. Lett. 77, 2002 (1996).

[3] N. Satomi, A. Takahara and Kajiyama, Macromolecules 32, 4474 (1999).

[4] T. Kanaya, T. Miyazaki, H. Watanabe, K. Nishida, H. Yamano, S. Tasaki, and D. B. Bucknall, Polymer 44, 3769 (2003); T. Miyazaki, K. Nishida, and T. Kanaya, Phys. Rev. E. 69, 061803 (2004).

[5] R. Inoue, T. Kanaya, K. Nishida, I. Tsukushi, and K. Shibata, Phys. Rev. Lett. 95, 56102 (2005).

[6] R. Inoue, T. Kanaya, K. Nishida, I. Tsukushi, and K. Shibata, Phys. Rev. E. 74, 021801 (2006).

[7] R. Inoue, T. Kanaya, K. Nishida, I. Tsukushi, and K. Shibata, Phys. Rev. E. (2008), in press.

[8] R. Inoue, T. Kanaya, K. Nishida, I. Tsukushi, J. Taylor, S. Levett, B. Gabrys, Eur. Phys. J. E 24, 55-60 (2007)

[9] Y. Ogino, H. Fukushima, N. Takahashi, G. Matsuba, K. Nishida, T. Kanaya, Macromolecules 39, 7617-7642 (2006).

[10] T. Kanaya, T. Takayama, Y. Ogino, G. Matsuba, K. Nishida, Lecture Notes in Physics (Springer) 714, 87-96 (2007).

[11]T. Kanaya, G. Matsuba, Y. Ogino, K. Nishida, H. M. Shimazu, T. Shinohara, T. Oku, J. Suzuki, T. Otomo, Macromolecules 40, 3650-3654 (2007).

[12] Y. Ogino, H. Fukushima, N. Takahashi, G. Matsuba, K. Nishida, T. Kanaya, Polymer 47, 5669-5677 (2006)

[13] T. Kanaya, N. Takahashi, K. Nishida, H. Seto, M. Nagao, T. Takeda, Phys. Rev., E 71, 011801 (2005)

[14] T. Kanaya, N. Takahashi, K. Nishida, H. Seto, M. Nagao, T. Takeda, Physica, B 285/386, 676 (2006).

[15] T. Kanaya, M. Ohkura, K. Kaji K, M. Furusaka, M. Misawa, Macromolecules 27, 5609-5615 (1994).

[16] H. Takeshita, T. Kanaya, K. Nishida, K. Kaji, Macromolecules 32, 7815-7819 (1999). 